\title{
Taxonomy and Emended Description of Strains of Erwinia Isolated from Musa paradisiaca Linnaeus
}

\author{
ROBERT S. DICKEY AND JORGE I. VICTORIA† \\ Department of Plant Pathology, Cornell University, Ithaca, New York 14853
}

\begin{abstract}
The phytopathogenic bacterium which causes soft rot of the pseudostem of Musa paradisiaca Linnaeus has been designated previously as Erwinia carotovora subsp. paradisiaca, E. paradisiaca, E. carotovora subsp. chrysanthemi, and $E$. chrysanthemi. Thirty strains were examined and compared with strains of closely related Erwinia species and their subspecies. The strains from M. paradisiaca were found to be phenotypically similar to $E$. chrysanthemi strains on the basis of the following characteristics: pectate degradation; production of phosphatase, indole, acetoin, and acid from ethanol; growth at 36 to $37^{\circ} \mathrm{C}$; susceptibility to erythromycin; gas from glucose; utilization of malonate; no growth in $5 \% \mathrm{NaCl}$; and no production of acid from $\alpha$-methyl- $d$-glucoside, trehalose, maltose, lactose, or palatinose. They could be distinguished from 322 strains of $E$. chrysanthemi isolated from 22 other plant hosts by the following phenotypic properties: production of acid from $D$-arabinose and raffinose; utilization of sodium tartrate; no production of lecithinase or of acid from inulin, mannitol, or sorbitol; and inability to liquefy gelatin.
\end{abstract}

Soft rot of the pseudostem of plantain (Musa paradisiaca Linnaeus) was initially observed in Puerto Tejada, Colombia, a small town near Cali (13). The disease later spread into the Cauca Valley and eventually into other areas of Colombia. The pathogen may cause an 80 to $90 \%$ reduction of production within 5 years after initial infection in a plantation. Thus far, the pathogen and disease have been identified and reported only in Colombia.

Llanos (13) used pathogenicity tests to demonstrate a bacterium as the causal agent. After completion of some physiological tests, Fernández-Borrero tentatively concluded that the bacterium should be included in the genus Erwinia (9). Victoria and Barros (22) studied the pathogen more thoroughly and reported that the bacterium was similar to $E$. carotovora, but they also noted that there were some striking differences. They proposed that the pathogen be designated $E$. carotovora subsp. paradisiaca. Fernández-Borrero and López-Duque (10) verified the differences between the plantain strains and $E$. carotovora and elevated the pathogen to specific rank as E. paradisiaca. Barzic et al. (3) included a strain from $M$. paradisiaca, supplied by Dickey, in a comparative study with other erwiniae and placed the strain in a group designated $E$. carotovora subsp. chrysanthemi. Samson and Nassan-Agha (17) have identified three

†Present address: Department of Plant Pathology, Instituto Colombiano Agropecuario, Apartado Aéreo 233, Palmira, Co. lombia, South America. plantain strains (from Dickey) as E. chrysanthemi.

Several of our original strains of the plantain pathogen and several from culture collections were examined, and the phenotypic characters were determined by the procedures used for the separation of Erwinia species in Bergey's Manual of Determinative Bacteriology (12). Strains of the " $E$. carotovora group" were included in the comparative study reported here.

\section{MATERIALS AND METHODS}

Bacterial strains. The 30 strains of the pathogen isolated from soft-rotted pseudostems of $M$. paradisiaca collected in Colombia are listed in Table 1 . The strains were compared with 322 strains of $E$. chrysanthemi, 77 strains of $E$. carotovora subsp. carotovora, 16 strains of $E$. carotovora subsp. atroseptica, 2 strains of E. cypripedii, and 1 strain of E. rhapontici; the details concerning these strains are listed elsewhere (7). All strains were maintained on Difco nutrient agar at $4^{\circ} \mathrm{C}$.

Morphological and cultural properties. The Hucker modification of Gram stain (19) was used to observe cell morphology, and flagella were observed by the method of Blenden and Goldberg (4). Cultural characteristics and pigment production were determined on nutrient agar and yeast extract-dextrose$\mathrm{CaCO}_{3}$ agar (2).

Physiological and biochemical properties. The methods used for determining the physiological and biochemical characters of the strains have been described previously (7).

Base composition of DNA. The deoxyribonucleic acid (DNA) of selected strains was extracted and 
TABLE 1. Strains of Erwinia isolated from M. paradisiaca in Colombia, South America, and included in this study

\begin{tabular}{|c|c|c|c|}
\hline $\begin{array}{c}\text { Laboratory } \\
\text { no. }\end{array}$ & Strain & Source $^{a}$ & Location \\
\hline 221 & 141 & 1 & La Cumbre, Palmira \\
\hline 228 & 322 & 1 & La Cumbre, Palmira \\
\hline 235 & $A-110$ & 2 & Palmira, Valle \\
\hline 236 & B-131 & 2 & Palmira, Valle \\
\hline 324 & C-15 & 2 & Collection of Plantain Varieties, Palmira \\
\hline 325 & $\mathrm{C}-16$ & 2 & Collection of Plantain Varieties, Palmira \\
\hline 326 & $\mathrm{C}-18$ & 2 & Collection of Plantain Varieties, Palmira \\
\hline 327 & $\mathrm{C}-415$ & 2 & Collection of Plantain Varieties, Palmira \\
\hline 329 & $\mathrm{C}-425$ & 2 & Collection of Plantain Varieties, Palmira \\
\hline 330 & C-426 & 2 & Collection of Plantain Varieties, Palmira \\
\hline 331 & $\mathrm{C}-427$ & 2 & Collection of Plantain Varieties, Palmira \\
\hline 399 & St L-13-1 & 2 & Hacienda Santa Lucia \\
\hline 400 & St L-13-3 & 2 & Hacienda Santa Lucia \\
\hline 401 & St L-14-1 & 2 & Hacienda Santa Lucia \\
\hline 332 & St L-25 & 2 & Hacienda Santa Lucia \\
\hline 333 & St L-35 & 2 & Hacienda Santa Lucia \\
\hline 334 & St L-36 & 2 & Hacienda Santa Lucia \\
\hline 335 & St L-37 & 2 & Hacienda Santa Lucia \\
\hline 337 & St L-39 & 2 & Hacienda Santa Lucia \\
\hline 338 & $\mathrm{G}-331$ & 2 & ICA, Centro Experimental, Palmira \\
\hline 409 & $17-22$ & 2 & Caicedonia \\
\hline 410 & $18-13$ & 2 & Caicedonia \\
\hline 414 & $20-23$ & 2 & Cerrito \\
\hline 416 & $22-3$ & 2 & Manizales \\
\hline 418 & $23-4$ & 2 & Manizales \\
\hline 419 & $24-2$ & 2 & Manizales \\
\hline 420 & $24-4$ & 2 & Manizales \\
\hline 443 & NCPPB 2511 & 3 & Cenicafé, Chinchiná \\
\hline 444 & NCPPB 2512 & 3 & Cenicafé, Chinchiná \\
\hline 445 & NCPPB 2513 & 3 & Cenicafé, Chinchiná \\
\hline
\end{tabular}

" 1, G. A. Granada, Instituto Colombiano Agropecuario (ICA), Palmira; 2, J. I. Victoria, Instituto Colombiano Agropecuario, Palmira; 3, 0. Fernández-Borrero, Departamento de Biologia y Suelos, del Centro Nacional de Investigaciones de Cafe, Chinchiná, Caldas.

purified by the method of Marmur (15), and the guanine plus cytosine $(\mathrm{G}+\mathrm{C})$ composition was determined by the thermal denaturation technique (14) and by the use of a Gilford 240 spectrophotometer. The relationship between melting point temperature $\left(T_{m}\right)$ and $\mathrm{G}+\mathrm{C}$ content of different DNA samples in standard saline citrate (14) was represented by the following equation: moles percent $\mathrm{G}+\mathrm{C}=2.44\left(T_{m}-69.4\right)(6)$.

Pathogenicity. Cells to be used as inocula were grown on slants of yeast extract-dextrose-CaCO:3 agar for $24 \mathrm{~h}$ at $27^{\circ} \mathrm{C}$. Cells were removed from the medium by a dissecting needle and introduced into small pieces (4 by $8 \mathrm{~cm}$ ) of plantain pseudostem ( $M$. paradisiaca) from healthy mature plants, and each piece was placed in a closed petri dish with wetted filter paper. In addition, cells were collected on the tips of sterile toothpicks and were inserted near the base of 60 - to 80-day-old plantain seedlings (Musa balbisiana Linnaeus). The controls were prepared by the insertion of a sterile needle or toothpick into a pseudostem piece or seedling, respectively. The occurrence of tissue degradation was recorded at $4,6,8$, and 12 days after inoculation.

\section{RESULTS}

The bacterium isolated from $M$. paradisiaca was a gram-negative, non-sporeforming rod which occurred singly or in pairs. Cells from a 24-h-old nutrient agar culture had average dimensions of 0.6 by $1.7 \mu \mathrm{m}$. The cells were motile and peritrichous; four to six flagella were commonly discernible as previously reported (22). The colonies on nutrient agar after $24 \mathrm{~h}$ at $27^{\circ} \mathrm{C}$ were convex, slightly to moderately irregular and undulate, pale cream-colored, and butyrous and averaged 1.5 to $2.5 \mathrm{~mm}$ in diameter; on yeast extract-dextrose- $\mathrm{CaCO}_{3}$ agar, the colonies were convex or somewhat umbonate, irregular, undulate, light tan, butyrous, and 2.5 to $3.5 \mathrm{~mm}$ in diameter.

The phenotypic characteristics for which all strains of Erwinia from $M$. paradisiaca were positive include the following: facultatively anaerobic; pectate degradation; potato soft rot; gas 
from glucose; catalase production; phosphatase production; $\beta$-galactosidase production; indole production; nitrate reduction; growth at 36 and $39^{\circ} \mathrm{C}$; susceptibility to penicillin $\mathrm{G}(2 \mathrm{U})$; susceptibility to erythromycin $(15 \mu \mathrm{g}) ; \mathrm{H}_{2} \mathrm{~S}$ from sodium thiosulfate; $\mathrm{KCN}$ inhibition; utilization of sodium citrate, sodium malonate, sodium tartrate, and meso-tartrate; and acid from $\mathrm{D}$-fructose, D-galactose, D-mannose, D-arabinose, L-arabinose, D-ribose, $D$-xylose, L-rhamnose, D-cellobiose, D-melibiose, D-raffinose, glycerol, ethanol, esculin, salicin, and $\alpha$-D-galacturonic acid. The phenotypic characteristics for which all strains of Erwinia from M. paradisiaca were negative include the following: cytochrome oxidase production; casein hydrolysis; gelatin liquefaction; phenylalanine deamination; gluconate oxidation; blue pigment on yeast extract-dextrose- $\mathrm{CaCO}_{3}$ agar; arginine decarboxylase; growth in $5 \% \mathrm{NaCl}$; deoxyribonuclease production; urease production; lecithinase production; and acid from D-maltose, D-lactose, D-trehalose, palatinose, D-melezitose, starch, inulin, dextrin, D-mannitol, adonitol, dulcitol, D-sorbitol, $i$-inositol, and $\alpha$-methyl- $d$-glucoside.

All strains produced acetoin except strain 235 . All strains grew in $1 \%$ peptone medium (12) without carbohydrate and produced a slight increase ( 0.36 to 0.90 unit) in the $\mathrm{pH}$ of the medium at 7 days after inoculation at $27^{\circ} \mathrm{C}$. Slight to moderate growth also occurred in the basal medium of Ayers et al. (1) without carbohydrate, and a slight decrease in $\mathrm{pH}$ (0.05 to 0.51 unit) was recorded.

The results for the $T_{m}$ and $\mathrm{G}+\mathrm{C}$ determinations of the three strains isolated from $M$. paradisiaca, two strains of $E$. chrysanthemi, and a strain of Escherichia coli are given in Table 2. There were no striking differences in the $T_{m}$ and

TABLE 2. DNA base composition of selected strains of Erwinia and a strain of $E$. coli

\begin{tabular}{lcc}
\hline \multicolumn{1}{c}{ Strain } & $\begin{array}{c}T_{m} \\
\left({ }^{\circ} \mathrm{C}\right)\end{array}$ & $\begin{array}{c}\text { G+C content } \\
\text { of DNA } \\
\text { (mol\%) }\end{array}$ \\
\hline $221^{a}$ & 91.5 & 54.0 \\
$235^{a}$ & 91.8 & 54.7 \\
$327^{a t}$ & 91.7 & 54.4 \\
$\mathrm{~B}-46^{b}$ & 92.0 & 55.1 \\
${\text { NCPPB } 2538^{c}}_{\text {E. coli }}$ & 91.9 & 54.7 \\
\hline
\end{tabular}

\footnotetext{
"Isolated from M. paradisiaca.

${ }^{b} E$. chrysanthemi isolated from philodendron (Philodendron selloum).

" $E$. chrysanthemi isolated from corn (Zea mays).

"Strain obtained from Steve Klevickis (Department of Bacteriology, University of Wisconsin, Madison).
}
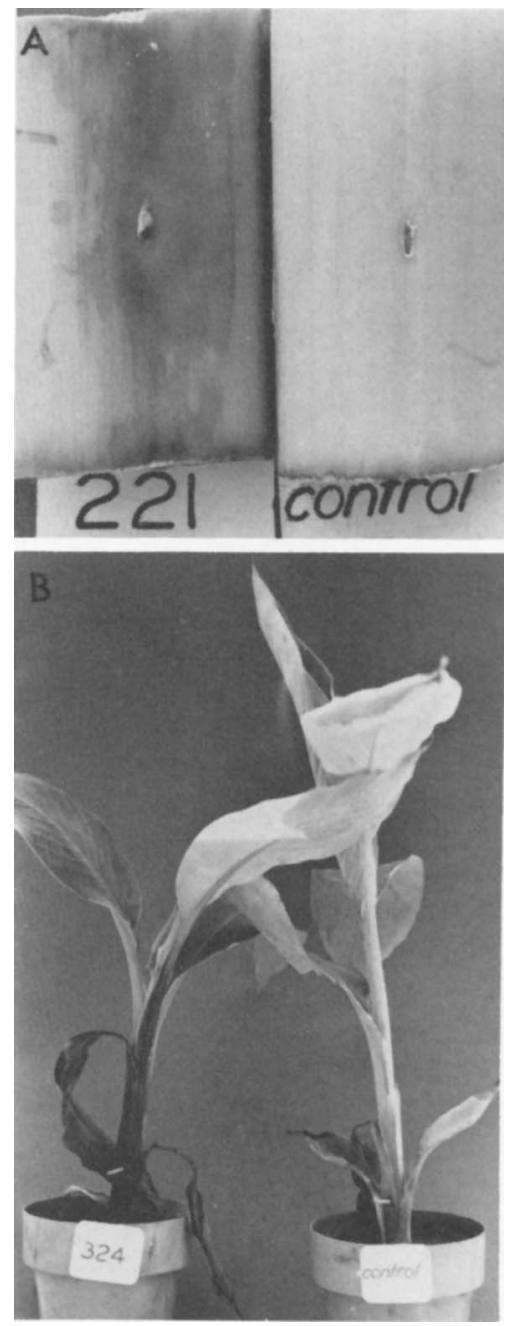

FIG. 1. Typical symptoms produced by strains of Erwinia isolated from M. paradisiaca. (A) Development of pink to light-brown color and soft rot of pseudostem tissue (M. paradisiaca) around point of insertion of cells of strain 221 at 6 days after inoculation (left). Peudostem tissue punctured with sterile needle (right). (B) Dark-brown discoloration and soft rot of stem and leaf tissues of 80-day-old plantain seedlings (M. balbisiana) at 12 days after inoculation with cells of strain 324 (left). Toothpick infested with cells of strain 324 (left) and sterile toothpick (right) near base of stem denote the points of inoculation.

$\mathrm{G}+\mathrm{C}$ determinations of the plantain strains and the $E$. chrysanthemi strains.

All strains from $M$. paradisiaca caused tissue degradation of plantain pseudostem pieces and plantain seedlings. Typical results are shown in Fig. 1. 


\section{DISCUSSION}

The problems inherent in the taxonomy of the soft-rot group of Erwinia species have been reviewed elsewhere $(5,7,8,11,12,20)$. The 30 strains from $M$. paradisiaca are very similar to $E$. chrysanthemi strains (Table 3) when compared with the results of comparative studies previously reported for phenotypically similar Erwinia species and their subspecies $(5,7,8,11$, 18). Barzic et al. (3) designated one strain (their no. 1451) from plantain as $E$. carotovora subsp. chrysanthemi, and Samson and Nassan-Agha (17) designated three strains as $E$. chrysanthemi based primarily on the following characteristics: production of indole and phosphatase; growth at $37^{\circ} \mathrm{C}$; utilization of malonate; no production of acid from $\alpha$-methylglucoside or lactose; and no production of reducing substances from sucrose. These characteristics agree with our results (Table 3).

The DNA base compositions of the three plantain strains and two strains of $E$. chrysanthemi (Table 2) are in close agreement with the results obtained with strains of $E$. chrysanthemi and Escherichia coli $(16,21)$ and support the similarity of the five strains.

Strains of $E$. chrysanthemi have been isolated and identified from many host plants (7). The plantain strains can be distinguished from strains of E. chrysanthemi from other hosts by the following physiological properties: production of acid from D-arabinose and raffinose; utilization of sodium tartrate; inability to liquefy gelatin; no production of lecithinase; and no production of acid from mannitol, sorbitol, or inulin. Thus, the plantain strains constitute a new phenotypic subdivision, VI (Table 4). Subdivisions I through $\mathrm{V}$ maintain their original identity and incorporate the same strains as previously described (7), although the scheme for separation of the subdivisions has been modified in Table 4. Samson and Nassan-Agha (17) have divided 129 strains of $E$. chrysanthemi from 17 hosts into eight groups, three of which are listed as biovars. They used six properties to separate the three plantain strains from the strains included in the three biovars and other groups. Four of the properties (acid production from D-arabinose, acid production from raffinose, no acid production from mannitol, and utilization of tartrate) are included in Table 4, and two properties (acid production from melibiose and lack of arginine degradation) agree with our results (see above).

A recent proposal has been made (23) that the term pathovar be used for phytopathogenic bacteria at the infrasubspecific level. Strains which possess a limited number of phenotypic differences and a unique host range are considered

TABLE 3. Characteristics selected to indicate the relationship between Erwinia strains from M. paradisiaca and phenotypically similar Erwinia species and their subspecies ${ }^{a}$

\begin{tabular}{|c|c|c|c|c|c|c|}
\hline Characteristic & $\begin{array}{c}\text { Erwinia } \\
\text { strains } \\
\text { from } M . \\
\text { paradisiaca }\end{array}$ & $\begin{array}{c}E . \\
\text { chrysan. } \\
\text { themi }\end{array}$ & $\begin{array}{c}E . \\
\text { carotovora } \\
\text { subsp. } \\
\text { carotovora }\end{array}$ & $\begin{array}{c}E . \\
\text { carotovora } \\
\text { subsp. } \\
\text { atroseptica }\end{array}$ & $\begin{array}{c}E . \\
\text { cypripedii }\end{array}$ & $\begin{array}{c}E . \\
\text { rhapontici }\end{array}$ \\
\hline Pectate degradation & $+^{b}$ & + & + & + & - & - \\
\hline Phosphatase production & + & + & - & - & $\mathbf{v}$ & $\mathbf{v}$ \\
\hline Growth at 36 to $37^{\circ} \mathrm{C}$ & + & + & + & - & + & $\mathbf{v}$ \\
\hline Indole production & + & + & - & - & - & - \\
\hline Acetoin production & + & + & + & + & - & + \\
\hline Susceptibility to erythromycin & + & + & - & - & + & + \\
\hline Gas from glucose & + & + & $\mathbf{v}$ & $\mathrm{v}$ & + & - \\
\hline Growth in $5 \% \mathrm{NaCl}$ & - & $\mathrm{v}$ & + & + & + & + \\
\hline Utilization of malonate & + & + & - & - & $\mathbf{v}$ & + \\
\hline \multicolumn{7}{|l|}{ Acid from: } \\
\hline$\alpha$-Methyl- $d$-glucoside & - & - & - & + & - & $v$ \\
\hline Trehalose & - & - & + & + & + & + \\
\hline Maltose & - & - & $\mathbf{v}$ & + & + & + \\
\hline Lactose & - & $\mathbf{v}$ & + & + & - & + \\
\hline Palatinose & - & - & - & + & - & + \\
\hline Ethanol & + & + & - & - & + & - \\
\hline
\end{tabular}

" The phenotypic results for the Erwinia species and their subspecies are derived from previously published data $(5,7,8,11,18)$. Two or more authors report the following for all species: facultatively anaerobic; reduction of nitrate; production of catalase and $\mathrm{H}_{2} \mathrm{~S}$ and of acid from fructose, galactose, mannose, arabinose, ribose, glucose, cellobiose, glycerol, mannitol, esculin, and salicin; utilization of citrate; and no production of oxidase, urease, arginine decarboxylase, or acid from adonitol. $\beta$-Galactosidase production and no production of deoxyribonuclease are reported by one or more authors.

${ }^{b}$ Symbols:,$+ 80 \%$ or more strains positive;,$- 80 \%$ or more strains negative; $v, 21$ to $79 \%$ strains positive. 
TABLE 4. Comparison of some phenotypic characteristics of Erwinia strains from $M$. paradisiaca with those of strains of $E$. chrysanthemi isolated from other hosts

\begin{tabular}{|c|c|c|c|c|c|c|}
\hline \multirow{2}{*}{ Characteristic } & \multicolumn{6}{|c|}{ Subdivision" (no. of strains) } \\
\hline & I (22) & II (3) & III (25) & IV (199) & V (73) & VI (30) \\
\hline \multicolumn{7}{|l|}{ Acid from: } \\
\hline D-(-)-mannitol & $t^{b}$ & + & + & + & + & - \\
\hline D-(-)-sorbitol & + & + & + & + & + & - \\
\hline D-(-)-arabinose & + & - & - & + & - & + \\
\hline D- $(+)$-raffinose & - & + & + & + & $+(51)$ & + \\
\hline Inulin & - & - & + & - & + & - \\
\hline Utilization of sodium tartrate & + & + & - & + & + & + \\
\hline Lecithinase & + & + & + & + & $+(93)$ & - \\
\hline Gelatin liquefaction & + & + & + & + & $+(90)$ & - \\
\hline
\end{tabular}

\footnotetext{
${ }^{a}$ See Dickey (7) for original hosts of strains in infrasubspecific subdivisions I through V; subdivision VI includes only strains isolated from $M$. paradisiaca.
}

${ }^{b}$ Symbols: +, all strains positive; -, all strains negative; ( ), percentage of strains.

eligible for designation as pathovars. The following five pathovars of $E$. chrysanthemi have been proposed: diffenbachiae, parthenii, zeae, chry. santhemi (23), and dianthicola (7). Thus far, pathogenic bacterial strains which possess the phenotypic characters reported here (see above and Table 4) are unusual because they have been isolated only from $M$. paradisiaca plants collected in Colombia. If it is eventually determined that the plantain strains have a unique host range, it is proposed that the strains isolated from $M$. paradisiaca be designated $E$. chrysanthemi pathovar paradisiaca. It is suggested that strain B-131 (strain PDDCC 2349, Plant Disease Division Culture Collection, Aukland, New Zealand) be designated the reference strain.

\section{ACKNOWLEDGMENTS}

We thank Cathy Zumoff for technical assistance during the phenotypic studies and Steve Klevickis for the $T_{m}$ determinations.

\section{REPRINT REQUESTS}

Address reprint requests to: Dr. Robert S. Dickey, Department of Plant Pathology, Cornell University, Ithaca, NY 14583.

\section{LITERATURE CITED}

1. Ayers, S. H., P. Rupp, and W. T. Johnson. 1919. A study of the alkali-forming bacteria in milk. U.S. Department of Agriculture bulletin 782. U.S. Department of Agriculture, Washington, D.C.

2. Baigent, N. L., J. E. DeVay, and M. P. Starr. 1963 Bacteriophages of Pseudomonas syringae. N.Z. J. Sci 6:75-100.

3. Barzic, M.-R., R. Samson, and A. Trigalet. 1976. Pourriture bactérienne de la tomate cultivée en serre. Ann. Phytopathol. 8:237-240.

4. Blenden, D. C., and H. S. Goldberg. 1965. Silver impregnation stain for Leptospira and flagella. J. Bacteriol. 89:899-900.

5. Bonnet, P. 1970. Etude compareé des caractères biochimiques du Pectobacterium parthenii (Starr) Hell. var. dianthicola (Hell.) et de différentes souches de Pecto. bacterium, d'Aerobacter et de Serratia. Ann. Phytopathol. 2:209-225.

6. De Ley, J. 1970. Reexamination of the association between melting point, buoyant density, and chemical base composition of deoxyribonucleic acid. J. Bacteriol. 101:738-754.

7. Dickey, R. S. 1979. Erwinia chrysanthemi: a comparative study of phenotypic properties of strains from several hosts and other Erwinia species. Phytopathology 69: 324-329.

8. Dye, D. W. 1969. A taxonomic study of the genus Erwinia. II. The "carotovora" group. N.Z. J. Sci. 12:81-97.

9. Fernández-Borrero, O. 1967. Estudios taxonómicos de la bacteria que causa la pudrición acuosa del pseudotallo del plátano (Musa paradisiaca), p. 70. In Memorias IV Congreso Nacional de Ingenieros Agrónomos, Barranquilla, 20-24 Noviembre, Bogotá. Agricultura Tropical, Bogota.

10. Fernández-Borrero, O., and S. López-Duque. 1970. Pudricion acuosa del suedo tallo del plátano (Musa paradisiaca) causada por Erwinia paradisiaca, n. sp. Cenicafe 21:3-44.

11. Graham, D. C. 1972. Identification of soft rot coliform bacteria, p. 273-279. In Proceedings of the Third International Conference on Plant Pathology and Bacteriology. Pudoc, Wageningen, The Netherlands.

12. Lelliott, R. A. 1974. Genus XII. Erwinia Winslow, Broadhurst, Buchanan, Krumwiede, Rogers and Smith 1920 , p. 332-340. In R. E. Buchanan and N. E. Gibbons (ed.), Bergey's manual of determinative bacteriology, 8 th ed. The Williams \& Wilkins Co., Baltimore.

13. Llanos, M. C. 1967. Una nueva enfermedad del platano en el Valle del Cauca: la bacteriosis. Agric. Trop. 23: 806-812.

14. Mandel, M., and J. Marmur. 1968. Use of ultraviolet absorbance-temperature profile for determining the guanine plus cytosine content of DNA. Methods Enzymol. 12B:195-206.

15. Marmur, J. 1961. A procedure for the isolation of deoxyribonucleic acid from microorganisms. J. Mol. Biol. 3: 208-218.

16. Murata, N., and M. P. Starr. 1974. Intrageneric clustering and divergence of Erwinia strains from plants and man in the light of deoxyribonucleic acid segmental homology. Can. J. Microbiol. 20:1545-1565.

17. Samson, R., and N. Nassan-Agha. 1978. Biovars and serovars among 129 strains of Erwinia chrysanthemi, p. 547-553. In Proceedings of the Third International 
Conference on Plant Pathology and Bacteriology. Pudoc, Wageningen, The Netherlands.

18. Sellwood, J. E., and R. A. Lelliott. 1978. Internal browning of hyacinth caused by Erwinia rhapontici. Plant Pathol. 27:120-124.

19. Society of American Bacteriologists. 1957. Manual of microbiological methods. McGraw-Hill Book Co., Inc., New York.

20. Starr, M. P., and A. K. Chatterjee. 1972. The genus Erwinia: enterobacteria pathogenic to plants and animals. Annu. Rev. Microbiol. 26:389-426.
21. Starr, M. P., and M. Mandel. 1969. DNA base composition and taxonomy of phytopathogenic and other enterobacteria. J. Gen. Microbiol. 56:113-123.

22. Victoria, J. I., and O. Barros. 1969. Etiologia de una neuva enfermdad bacterial del plátano (Musa paradisiaca L.) en Colombia. Inst. Colomb. Agropecu. Revista ICA 4:173-190.

23. Young, J. M., D. W. Dye, J. F. Bradbury, C. G. Panagopoulos, and C. F. Robbs. 1978. A proposed nomenclature and classification for plant pathogenic bacteria. N.Z. J. Agric. Res. 21:153-177. 